The total number of nestboxes checked for 1975 by regulars and volunteers was 789 . A summary of the occupants shows: Mountain Bluebirds 201: Eastern Bluebirds 5; cross breeding 1: Bluebirds (either species) 141; Tree Swallows 251; House Wrens 14; House Sparrows 74; mice 37; Starlings 2; grain 2; empty 37 ; vandalized 24 .

If the good fall weather holds, large portions of the neglected nestboxes will be cleaned out by volunteers, ready for an active summer in 1976.
The Junior Birders were represented by Chris Martin and Daryl Neustater at the 93rd Stated Meeting of the A.O.U. at the University of Manitoba, Winnipeg, Their display showed the growth of their club's work through 15 years. Dr. David Krieg of State University, New York, presented his paper, "Species-recognition: Behaviour of Territorial Eastern and Mountain Bluebirds". The research was the result of studies done on our nestlines.

\title{
EASTERN PHOEBES IN BIRCH HILLS MUNICIPALITY
}

by MOE MARESCHAL and STUDENTS*

This Biology 20 project was inspried by J. A. Wedgwood's article on nighthawks in the Blue Jay of June, 1973. The Eastern Phoebe has been observed relatively frequently in the past in our area and it was decided to investigate the frequency of this bird in 1975. To do this we searched nesting sites in abandoned farms and under bridges. A large part of the Birch Hills Municipality was subdivided and one group was assigned to each division.

Group 1: Linda Stobbs and Cheryl Rude. Our first trip was made on June 11. In this trip we covered 42 miles and looked in 11 places, most of them containing more than one building. On

"Cheryl Rude, Linda Stobbs, Kathy Haug, Bev Miller, Debbie Braaten, Donna Silde, Bonnie Hovdebo, Lynn Njaa and Donna Kormish. Birch Hills Composite High School,

Birch Hills, Sask. SOJ OLO the outside of one large house, under a roof ledge, we found a phoebe nest containing three young. We saw the mother there also. In a couple of bins and old houses we found six Barn Swallow nests. We did not check the nests for contents. We also checked six bridges and saw birds flying out.

On Saturday, June 14, we tried to check the nests under the six bridges but the water was too deep. We checked a seventh bridge but no nests or birds were found (22 miles).

On Monday, June 16, we again checked six bridges and observed the birds we scared out. At two different bridges we saw two phoebes. Other birds we saw included Barn Swallows and sparrows. We could hear baby birds but could not see the exact location of the nests (15 miles).

We covered a total of 79 miles or approximately 20 square miles. 


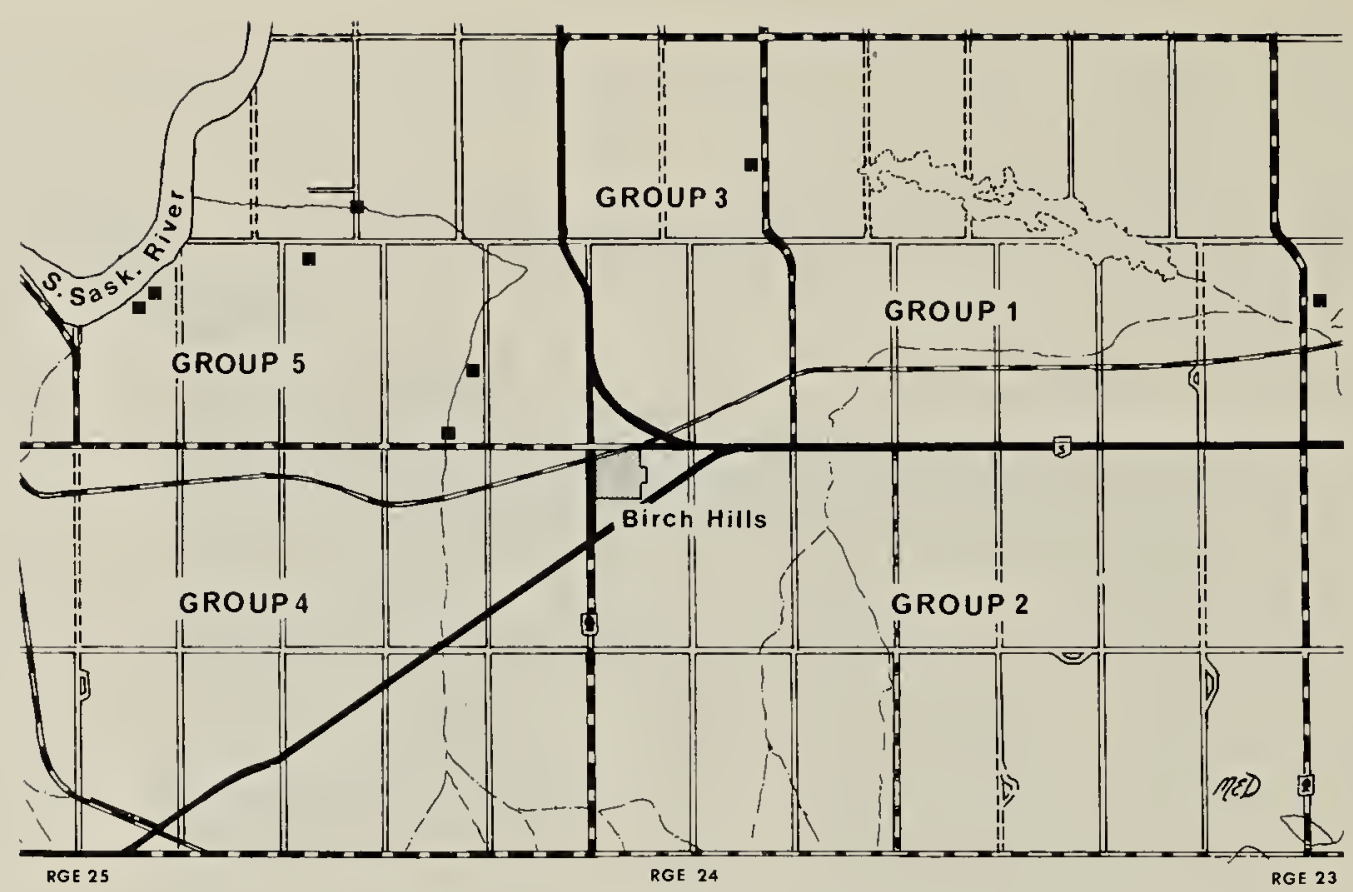

Group 2: Kathy Haug and Bev Miller. The area we were to cover was 28 square miles and within this area we drove 43 miles. We went to 10 farms which had old buildings. The other farms in our block were occupied and were, therefore, out of the scope of our investigation. We didn't find any nests because most of the buildings were boarded up.

Group 3: Debbie Braaten, Donna Silde and Bonnie Hovdebo. The area that we covered was 8 square miles. In this area we covered 17.5 miles by road. We went to 10 different places, and found one phoebe nest, which had three nestlings in it. We also found several Barn Swallow nests every place we went.

The phoebe nest was found on a rafter about a foot down from the ceiling. The building was about 7.5 feet at its peak, and it was damp and dark inside.

Group 4: Lynn Njaa, and Donna Kormish. Our area was 24 square miles. We drove about 23.5 miles. We stopped at 10 places and at one bridge. We found no evidence of phoebes or their nests. We did find one Barn Swallow nest.

Group 5: Moe Mareschal and family. This group covered 29 square miles and went 18 miles by road. We investigated five abandoned farms and two bridges. We found four phoebe nests at the farms. Each of two nests had four young in them and the other two nests had four eggs each. At one of the bridges we found a vacated phoebe nest. We also found five Barn Swallow nests.

Conclusion: During the interval from June 12 to 20,1975 , we went to a total of 46 abandoned farms and looked under 10 bridges. We drove a total of 181 miles, which represented approximately 109 square miles searched. We found two phoebe nests with three young each, two phoebe nests with four nestlings each, and two phoebe nests with four eggs each. We also found two phoebe nests under bridges where young were heard but not seen. Also one vacated nest was found. There was a total of 9 nests, more than 14 young birds, and 8 eggs.

In addition, 15 Barn Swallow nests and one Robin nest were found.

It is certain that some phoebes must have been missed, but the project at least gives some indication of the nesting density of phoebes and their dependence on old buildings and bridges for nesting sites.

The accompanying map indicates the approximate locations of the nests 